Published in final edited form as:

Curr Opin Toxicol. 2018 February ; 7: 133-139. doi:10.1016/j.cotox.2018.03.005.

\title{
ROLE OF THIOLS IN OXIDATIVE STRESS
}

\author{
Shahid P. Baba and Aruni Bhatnagar \\ ${ }^{1}$ Diabetes and Obesity Center, University of Louisville, Louisville KY, 40202 \\ 2Institute of Molecular Cardiology, University of Louisville, Louisville KY, 40202
}

\section{Abstract}

A well-regulated redox state is essential for normal physiological function and cellular metabolism. In most eukaryotic cells, protein cysteine thiols are most sensitive to fluctuations in the cellular redox state. Under normal physiological conditions, the cytosol has a highly reducing environment, which is due to high levels of reduced glutathione and complex system of redox enzymes that maintain glutathione in the reduced state. The reducing environment of the cytosol maintains most protein thiols in the reduced state; although some non-exposed cysteine could be present as disulfides. Upon physiological increase in cellular oxidants, such as due to growth factors, cytokines and thiol-disulfide exchange reactions, specific proteins could act as redox switches that regulate the conformation and activity of different proteins. This reversible post translational modification enables redox-sensitive dynamic changes in cell signaling and function. Physiological oxidative stress could lead to the formation of sulfenic acids, which are usually intermediate states of thiol oxidation that are converted to higher order oxidation states, intramolecular disulfides or mixed disulfides with glutathione. Such glutathiolation reactions have been found to regulate the function of several proteins involved in intracellular metabolism, signal transduction and cell structure. Excessive oxidative stress results in indiscriminate and irreversible oxidation of protein thiols, depletion of glutathione and cell death. Further elucidation of the relationship between changes in cell redox and thiol reactivity could provide a better understanding of how redox changes regulate cell function and how disruption of these relationships lead to tissue injury and dysfunction and the development of chronic diseases such as cancer and cardiovascular disease.

\section{INTRODUCTION}

Aerobic tissues are exposed to high levels of oxygen, which is required for maintaining respiration and metabolism. Tissues of the heart, brain and skeletal muscle contain abundant mitochondria that support rapid and efficient utilization of oxygen to meet their energy

Correspondence. Aruni Bhatnagar, Ph.D., Professor of Medicine, Division of Cardiovascular Medicine, 580 S Preston Street, Baxter II, Rm 421 EF, University of Louisville, Louisville, KY 40202, Phone: 502-852-5966, Fax: 502-852-3663.

Publisher's Disclaimer: This is a PDF file of an unedited manuscript that has been accepted for publication. As a service to our customers we are providing this early version of the manuscript. The manuscript will undergo copyediting, typesetting, and review of the resulting proof before it is published in its final citable form. Please note that during the production process errors may be discovered which could affect the content, and all legal disclaimers that apply to the journal pertain.

Conflicts of Interest

I have no conflicts of interest to declare 
demands. In these tissues, high rates of oxygen utilization lead to the generation of partially reduced forms of oxygen or reactive oxygen species (ROS), which are derived from the activity of electron transport chain in mitochondria. In metabolically active tissues, ROS are also generated during the course of metabolism, cell division, or enzymatic reactions. In addition, cells and tissues may be exposed to ROS derived from exposure to toxins, xenobiotics, and environmental pollutants. Due to their high reactivity, ROS can disrupt normal cell function, and if not detoxified, can lead to oxidative stress. A state of such oxidative stress, has been linked to the development of several degenerative diseases, including cancer and cardiovascular disease, as well as to progressive tissue damage and dysfunction associated with aging[1].

Although ROS react with most biomolecules, their major targets include unsaturated lipids and intracellular thiols. ROS-mediated oxidation of unsaturated lipids leads to the production of a large number of reactive intermediates and products such as hydroperoxides and carbonyls such as 4-hydroxy trans-2-nonenal and acrolein [2,3]. Being strong electrophiles, the intermediates of lipid peroxidation react avidly with intracellular thiols. In addition, the removal of lipid peroxidation products is mediated by an array of detoxifying enzymes that use thiols as reducing equivalents [4-6]. Thus, both enzymatic and nonenzymatic reactions of lipid peroxidation products lead to utilization, and often depletion, of intracellular thiols. Due to their high nucleophilicity, thiols in peptides and proteins are particularly vulnerable to direct oxidation by ROS and oxidation of thiols results in alterations in protein structure and function. Thus, thiols not only represent the most vulnerable targets of ROS and related oxidants, but they also represent a versatile and robust defense system against biochemical perturbations caused by oxidative stress. In addition, some protein thiols are selectively oxidized by low, physiological levels of oxidants, and such oxidative modifications play an important role in signal transduction, metabolism, as well as proliferation and cell death.

In most aerobic cells, the major non-protein thiol is glutathione (GSH); a tripeptide (gammaGlu-Cys-Gly) that can be oxidized to its corresponding disulfide (GSSG). The intracellular concentration of GSH varies from 0.1 to $10 \mathrm{mM}$ [7] [8]. The reduced redox state due to high intracellular concentrations of GSH is required to maintain protein thiols in a reduced state and to support a variety of redox reactions for reducing ROS, detoxifying xenobiotics, and facilitating cell signaling. The importance of thiol equilibrium in maintaining the function of normal aerobic tissues such as the myocardium is underscored by the observations that depletion of glutathione increases myocardial ischemia-reperfusion injury [9] and pretreatment with $\mathrm{N}$-acetylcysteine promotes post-ischemic recovery of function[10,11]. Although the mechanisms by which glutathione prevents ischemic injury remains unclear, recent work suggests that ROS generated during ischemia-reperfusion result in excessive lipid peroxidation, characterized by the generation of lipid peroxidation derived products such as HNE and acrolein [12-14]. Thus, glutathione, by removing these reactive, and potentially damaging species could prevent tissue damage and injury. This possibility is supported by our recent observation that deletion of GST-P, which catalyzes the conjugation between GSH and unsaturated lipid peroxidation derived aldehydes such as acrolein increases infarct size in mice subjected to coronary ligation [15]. Although deletion of GSTP did not affect the production of free radicals or glutathione depletion, it increased the 
accumulation of proteins adducted to acrolein in the ischemic heart. These observations suggest that the GSH-GSTP system supports the removal of lipid peroxidation products in the heart and it prevents changes in myocardial ion channels and metabolic process during episodes of ischemia.

\section{REDOX SWITCHES}

The high levels of reduced glutathione in the cytosol maintains a highly reduced redox state. However, different compartments and organelles within the cell are maintained at different redox potentials, and are not at equilibrium with each other. For example, in contrast to the cytosol, the ER maintains a more oxidized redox state $[16,17]$ in order to assist protein folding and maintenance of disulfide bridges in secreted proteins in which disulfide bridges impart structural rigidity and prevent spurious oxidation in the more oxidizing extracellular environment. Similarly, the mitochondria maintain their own distinct intracellular redox state [18]. In the cytosol, most solvent exposed thiols are in the reduced form, although some proteins maintain distinct states of thiol oxidation which is reversibly altered in response to physiological oxidative signaling. The human genome contains $>21,000$ cysteine residues[19], distributed on the surface of proteins or buried within globular domains [20]. Some of these cysteines can form disulfides even under reduced and non-oxidizing conditions. The formation and breakdown of such disulfide bonds within globular domains can change the conformation of the molecule as well as its function [21]. For instance, the DNA binding of FosB bZIP domain of JunD is controlled by a redox switch represented by an intramolecular disulfide bond [22]. Similar, disulfide switches that regulate protein activity have been found in several other proteins such as the histone lysine demethylase KDMIA [23], the Lon protease [24], superoxide dismutase (SOD) [25], C-reactive protein [26] and BK channels [27]. In addition, cysteine switches and the formation of disulfide bonds can also regulate the secretion and intracellular trafficking e.g., MMP-9; [28], or extracellular events such as thrombus formation (e.g., by the reduction of disulfide bonds on plasma vitronectin by secreted protein disulfide isomerase; [29].

To impart specificity of function and signaling, the formation of disulfide bonds in the cytosol is tightly regulated and adventitious thiol oxidation is readily reversed by the thioredoxin-thioredoxin reductase system, which operates independent of glutathione-linked systems. Protein disulfides are also reduced by glutaredoxin (Grx), but the disulfide forms of glutaredoxin is reduced by GSH. However, both the thioredoxin and Grx systems seem not be general mechanisms for maintaining protein thiols in the reduced state, but they assist in preserving thiols in specific proteins such as protein kinases, transcriptional regulators and ribonucleotide reductase. Thioredoxin in particular has been shown to regulate several signal transduction pathways such as those mediated by ASK-1, NF-kB, PTEN and AP-1 and the NLRP-3 inflammasome [30], suggesting that thiol-disulfide exchange reactions are critical components of cell signaling machinery, such that thiols switches could be turned on and off to activate or deactivate specific signaling pathways and trigger critical decisions of cell growth, proliferation and death. Such reactions include reduction of hydrogen peroxide or lipid hydroperoxides by glutathione peroxidases, detoxification of lipid peroxidation products by glutathione S-transferases, reduction of dehydroascorbate, and glutaredoxinmediated removal of protein disulfides. In addition, glutathione can directly prevent the 
oxidation of protein thiols by thiol-disulfide exchange and by forming mixed disulfides. During the formation of mixed disulfides, the binding of GSH to protein thiols results in the addition of a glutathione molecule to the protein leading to the formation of glutathiolated or glutathionylated proteins.

\section{PROTEIN SULFENIC ACIDS}

While the redox sensitivity of several proteins could be linked to the formation and dissolution of disulfide switches, other proteins are regulated by the formation of proteinsulfenic acids. Sulfenic acids (Cys-SOH) represent another reversible mode of thiol oxidation that upon oxidation could lead to more oxidized, irreversible oxidation states sulfinic $\left(\mathrm{Cys}-\mathrm{SO}_{2} \mathrm{H}\right)$ or sulfonic $\left(\mathrm{Cys}-\mathrm{SO}_{3} \mathrm{H}\right)$ acids. Conversation of sulfenic acids to disulfides serves as a molecular, redox switch, whereas their oxidation to the more oxidized forms (sulfinic and sulfonic acids) is indicative of oxidative injury such as that due to myocardial ischemia-reperfusion [31]. In some protein folding pathways, sulfenic acids are transient, intermediate states that lead to the formation of a metastable disulfide bond. For example, copper delivery by the copper chaperone for SOD (Ccs1) to immature SOD1 leads to the formation of a sulfenic acid that resolves to form a disulfide bond [32]. The formation of more stable sulfenic acids may be of physiological significance as well. Nox4-dependent hydrogen peroxide production due to laminar shear stress has been reported to lead to sulfenylation of SHP2 and eNOS activation [33], and cross-linking of the B-cell receptor leads to the formation of sulfenic acids in actin and several tyrosine phosphatases [34]. Inhibition of sulfenic acid formation blocked anti-IgM-induced cell division and tyrosine phosphorylation. Similarly, during lysophosphatidic acid (LPA)-mediated cell signaling, the LPA receptors are internalized into endosomes that contain NADPH oxidase. The oxidase generates hydrogen peroxide, which in turn results in the formation of sulfenic acids in proteins, such as Akt2 and PTP1B [35], suggesting that sulfenic acid formation may be an important post-translational modification that could regulate protein function. However, it is unclear whether protein function is regulated by the formation of the sulfenic acid by itself or its conversion to intramolecular disulfides or mixed disulfides with glutathione.

\section{PROTEIN GLUTATHIOLATION}

While intracellular disulfides are formed by reactions between reduced thiols within a protein, mixed disulfides are formed when protein thiols or sulfenic acids react with glutathione resulting in the formation of glutathiolated proteins. The $\mathrm{pKa}$ for protein cysteines is approximately 8.5 , hence only a small set of cysteine residues which are flanked by basic amino acids (arginine, histidine, lysine) are susceptible to deprotonation under physiological pH (7.0-7.4). Deprotonation of the cysteine thiols generates a highly reactive thiolate anion $\left(\mathrm{S}^{-}\right)$which attacks the sulfhydryl of GSSG followed by subsequent formation of disulfide. It appears that the thiol exchange between the thiolate and GSSG might be a straightforward mechanism for protein glutathiolation. However, levels of GSSG in cells are very low and tightly regulated [36,37], therefore, glutathiolation of proteins is usually enhanced during excessive generation of ROS [38] or by prior formation of protein sulfenic acids or protein nitrosation [39] [40,41]. Under oxidative stress, cysteines present in the basic environment of proteins are oxidized to highly reactive sulfenic acid, which readily 
react with glutathione. Indeed, several proteins such as aldose reductase [41,42] branched chain aminotransferase[43] hemoglobin [44] peroxiredoxins [45] actin [46] and inhibitor of nuclear factor kinase subunit [47] have been shown to be glutathiolated via formation of protein-sulfenic acids as intermediates. Glutathiolated proteins so formed have been implicated in regulating several physiological processes, such as deceleration of $\mathrm{Ca}^{2+}$ activated force development in ventricular myocytes (by glutathiolated myosin-binding protein $\mathrm{C}$; [48], increasing maximal rate of thapsigargin-sensitive $\mathrm{Ca}^{2+}$ uptake (mediated by glutathiolation of sarcoplasmic reticulum calcium ATPase; SERCA):[49], changes in Rac1 guanine nucleotide binding property[50] and enhancing angiogenic responses by SERCA glutathiolation [51,52]. Recent report suggests that glutathiolation also increases the susceptibility for protein degradation. For example, it has been shown that glutathiolation exposes the hydrophobic patches $\gamma \mathrm{C}$-crystallin which serves as a signal to degradation by ubiquitin proteasome pathway [53].

In addition to ROS, the cysteine thiols are also targeted by nitric oxide, S-nitrosothiols, or the highly reactive-peroxynitrate[41,46,54-56]. Proteomic studies with cardiac tissue, endothelial and smooth muscle cells identified 359 nitrosylated cysteine residues, corresponding to 258 proteins. Majority of these modifications were singly nitrosylated cysteine residues, suggesting that protein nitrosylation is highly specific [57] [58-61]. However, even though nitrosylated cysteine can act as an intermediate to stimulate protein glutathiolation, the specific mechanisms by which these proteins are glutathiolated is not clearly defined. It is possible that either the cysteine thiol is activated to nitro- $S$-cysteine which undergoes S-glutathiolation or $S$-nitroso-glutathione rather than NO mediates protein glutathiolation. Further work is required to distinguish between these mechanisms.

Protein glutathiolation can also be enhanced by catalysis mediated by glutathione Stransferase P (GSTP). This function of enzyme is based on auto-glutathiolation of GSTP at two critical amino acid residues, Cys47 and Cys101. At physiological pH, GSTP is glutathiolated, lowers the pKa of cysteine thiols (6.6) resulting in the formation of thiolate ions at the active site. The thiolate anion catalyzes the glutathiolation reaction by attacking the cysteine-SOH[62]. Indeed, it has been shown that the oxidation of a single conserved cysteine residue in peroxiredoxins decreases the peroxidase activity and binding of GSTP glutathiolates the oxidized cysteine and restores enzyme activity[63]. Similarly, studies from our laboratory have shown that during cardiac ischemia and reperfusion aldose reductase (AR) is converted to an active sulfenic form, which leads to an inactive glutathiolated form of the protein. Glutathiolation of AR is accelerated by GSTP and the appearance of glutathiolated AR is delayed in the hearts of GSTP null mice [64]. Recent studies with bone marrow derived dendritic cells from GSTP null mice showed that GSTP mediated glutathiolation of estrogen receptor alpha (ERa) at cysteines 221, 245, 417 and 447 alters the ERa mediated differentiation and metabolic function in dendritic cells [65].

In addition to GSTP mediated glutathiolation, protein glutathiolation could also be facilitated by glutaredoxin (Grx1). Depending upon the extent of oxidative stress, Grx 1 could exchange its role between glutathiolation and deglutathiolation [66]. This unique property of Grx 1 is facilitated by the low $\mathrm{pKa}$ (3.5) of cysteine residue present at the active site, which reacts with the glutathione-thiyl radical (GS.) and forms an enzyme disulfide 
anion radical intermediate (Grx1-SSG. ${ }^{-}$) and facilitating the glutathiolated protein formation [67]. Indeed glutathiolation of several proteins such as GAPDH [68], PTP1B [66] and actin[69] is promoted by Grx1 in the presence of GS. ${ }^{-}$radical.

Although glutathiolation of proteins can proceed either with or without enzyme catalysis, deglutathiolation of proteins appears to be tightly dependent on enzymatic catalysis. Several enzymes such as Grx, sulfiredoxin and protein-disulfides have been reported to exhibit deglutathiolating activity. Primarily located in the cytosol, Grx is considered far more efficient than other thiol-oxidoreductase enzymes ([66,70], Grx catalysis proceeds via a double displacement reaction in which the glutathiolated moiety of the protein is attacked by the thiolate anion of the enzyme forming the Grx-SSG. In the second step the Grx-SSG is deglutathiolated by glutathione producing GSSG and the reduced enzyme (Grx-S-) [71-73]. It has been reported that Grx deglutathiolates a diverse range of proteins including PTP1B [74], actin[75], RAS [76], and procaspase3 [77]. This deglutathiolating activity of Grx regulates important functions such as cardiac hypertrophy [78] actin polymerization[75], apoptosis[77] angiogenesis [79] and vasodilation [56].

\section{THIOL OXIDATION AND CHRONIC DISEASE: THE CASE OF CVD}

Maintenance of a reduced intracellular state is critical to the normal, physiological function of most tissues, and may be particularly critical to the functioning of cardiovascular tissues such as cardiac myocytes, endothelial cells and vascular smooth muscle cells. Not only are these tissues exposed to high levels of oxygen, they are also exposed to a variety of blood borne toxins and pollutants that pose a constant threat to their integrity and normal function. In addition, cardiovascular tissues, particularly the endothelium generates high levels of nitric oxide, which is required for relaxation of vascular smooth muscle cells. Generated from arginine by nitric oxide synthase, $\mathrm{NO}$ is a free radical that undergoes non-enzymatic reaction with glutathione. While NO, by itself is only weakly reactive with GSH, in the presence of oxygen it is converted to $\mathrm{N} 2 \mathrm{O} 3$, which reacts with glutathione to form nitrosoglutathione (GSNO). GSNO can undergo additional reactions with GSH to generate ammonia and GSSG. It can also facilitate the formation of glutathiolated proteins.

The maintenance of protein thiols in the reduced state or as intramolecular or mixed disulfides is a highly regulated process. Reversible and specific changes in the redox state in cysteine are important post-translational modifications that regulate protein function in a variety of intracellular processes. However, during oxidative stress, when ROS exposure or production overwhelms the anti-oxidative capacity of the cell, there could be indiscriminate cysteine oxidation, that is usually associated with marked injury and dysfunction. Such indiscriminate thiol oxidation has been found to be associated with several pathological and toxicological states [1], which not only results in non-specific oxidation of cellular thiols, but non-physiological formation of intramolecular or mixed disulfides. Upon return to nonoxidizing conditions, the thiols could be reduced back. However, if the injury is severe, this could lead to irreversible loss of protein function and potentially cell death. Thus, dysregulated thiol redox may be an index of disease risk. For example, cardiovascular disease is characterized by inappropriate plasma levels of sulfur containing amino acids [69] and GSTP polymorphism is associated with the risk of coronary heart disease [80]. In

Curr Opin Toxicol. Author manuscript; available in PMC 2019 February 01. 
addition, several studies have shown that elevated levels of gamma-glutamyl transferase $(\gamma \mathrm{GT})$ are associated with increased risk of cardiovascular disease such as coronary heart disease, stroke, arterial hypertension, heart failure, cardiac arrhythmias and all cause and CVD related mortality [81], suggesting that perturbed thiol metabolism may be common precursor of multiple manifestations of cardiovascular disease. A significant contributory role of perturbation of thiol metabolism in cardiovascular disease is supported by the observation that heart failure is associated with depletion of myocardial glutathione [82] and that atherosclerotic plaques show high levels of $\gamma \mathrm{GT}$ activity [81]. In addition, thiols regulate vascular function as well. Because of its ability to regulate the bioactivity of NO, the glutathione system plays an important role in regulating blood pressure, and may be critical determinant of hypertension[83]. GSNO has been found to play an important role in the transduction of angiogenic signals by ROS and formation of glutathiolated proteins has been suggested to have a beneficial effects in promoting tissue angiogenesis [79]. Although, the specific mechanisms by which thiols prevents, or contributes to cardiovascular pathological states, the ubiquitous dysregulation of thiol metabolism in disease cardiovascular tissues warrants further investigation and may lead to the identification of potentially useful interventions to prevent or ameliorate cardiovascular disease and its consequences. Such interventions may also prove useful in the prevention and treatment of other pathological states associated with oxidative stress.

\title{
Conclusions
}

Given that specific protein cysteine thiols have emerged as markers of redox status, which oscillates between glutathiolated, deglutathiolated, nitrosylated and oxidized states regulated by a series of enzymatic and non-enzymatic steps, and implicated in numerous biological processes (Fig. 1) makes them an attractive therapeutic target. However, the daunting challenge is to delineate the convergence of these steps with human pathology and develop strategies to target these particular pathways in a selective manner.

\section{Acknowledgments}

\author{
Funding: \\ Authors laboratories are funded by NIH grants HL 083320, HL094419, HL122581
}

\section{References}

1. Halliwell BGJ. Free radical in biology and medicine. Oxford University Press; Oxfore: 2015.

2. Esterbauer H, Zollner H, Scholz N. Reaction of glutathione with conjugated carbonyls. Z Naturforsch C. 1975; 30(4):466-473. [PubMed: 241172]

3. Awasthi YC. Toxicology of glutathione transferases. Taylor \& Francis; Galveston, USA: 2007.

4. Srivastava SK, Ramana KV, Bhatnagar A. Role of aldose reductase and oxidative damage in diabetes and the consequent potential for therapeutic options. Endocr Rev. 2005; 26(3):380-392. [PubMed: 15814847]

5. Srivastava S, Harter TM, Chandra A, Bhatnagar A, Srivastava SK, Petrash JM. Kinetic studies of fr-1, a growth factor-inducible aldo-keto reductase. Biochemistry. 1998; 37(37):12909-12917. [PubMed: 9737870]

6. Barski OA, Tipparaju SM, Bhatnagar A. The aldo-keto reductase superfamily and its role in drug metabolism and detoxification. Drug Metab Rev. 2008; 40(4):553-624. [PubMed: 18949601] 
7. Meister A, Anderson ME. Glutathione. Annu Rev Biochem. 1983; 52:711-760. [PubMed: 6137189]

8. Jones DP, Carlson JL, Mody VC, Cai J, Lynn MJ, Sternberg P. Redox state of glutathione in human plasma. Free Radic Biol Med. 2000; 28(4):625-635. [PubMed: 10719244]

9. Blaustein A, Deneke SM, Stolz RI, Baxter D, Healey N, Fanburg BL. Myocardial glutathione depletion impairs recovery after short periods of ischemia. Circulation. 1989; 80(5):1449-1457. [PubMed: 2805276]

10. Bartekova M, Barancik M, Ferenczyova K, Dhalla NS. Beneficial effects of n-acetylcysteine and nmercaptopropionylglycine on ischemia reperfusion injury in the heart. Curr Med Chem. 2018; 25(3):355-366. [PubMed: 28595547]

11. Ceconi C, Curello S, Cargnoni A, Ferrari R, Albertini A, Visioli O. The role of glutathione status in the protection against ischaemic and reperfusion damage: Effects of n-acetyl cysteine. $\mathrm{J}$ Mol Cell Cardiol. 1988; 20(1):5-13. [PubMed: 3367379]

12. Kato Y, Iwase M, Ichihara S, Kanazawa H, Hashimoto K, Noda A, Nagata K, Koike Y, Yokota M. Beneficial effects of growth hormone-releasing peptide on myocardial oxidative stress and left ventricular dysfunction in dilated cardiomyopathic hamsters. Circulation journal : official journal of the Japanese Circulation Society. 2010; 74(1):163-170. [PubMed: 19942785]

13. Benderdour M, Charron G, DeBlois D, Comte B, Des Rosiers C. Cardiac mitochondrial nadp+isocitrate dehydrogenase is inactivated through 4-hydroxynonenal adduct formation: An event that precedes hypertrophy development. J Biol Chem. 2003; 278(46):45154-45159. [PubMed: 12960146]

14. Srivastava S, Chandrasekar B, Gu Y, Luo J, Hamid T, Hill BG, Prabhu SD. Downregulation of cuzn-superoxide dismutase contributes to beta-adrenergic receptor-mediated oxidative stress in the heart. Cardiovascular research. 2007; 74(3):445-455. [PubMed: 17362897]

15. Conklin DJ, Guo Y, Jagatheesan G, Kilfoil PJ, Haberzettl P, Hill BG, Baba SP, Guo L, Wetzelberger K, Obal D, Rokosh DG, et al. Genetic deficiency of glutathione s-transferase $\mathrm{p}$ increases myocardial sensitivity to ischemia-reperfusion injury. Circ Res. 2015; 117(5):437-449. [PubMed: 26169370]

16. Hudson DA, Gannon SA, Thorpe C. Oxidative protein folding: From thiol-disulfide exchange reactions to the redox poise of the endoplasmic reticulum. Free Radic Biol Med. 2015; 80:171182. [PubMed: 25091901]

17. Hightower LE, Hendershot LM. Molecular chaperones and the heat shock response at cold spring harbor. Cell stress \& chaperones. 1997; 2(1):1-11. [PubMed: 9250390]

18. Shen D, Dalton TP, Nebert DW, Shertzer HG. Glutathione redox state regulates mitochondrial reactive oxygen production. J Biol Chem. 2005; 280(27):25305-25312. [PubMed: 15883162]

19. Jones DP. Radical-free biology of oxidative stress. American journal of physiology Cell physiology. 2008; 295(4):C849-868. [PubMed: 18684987]

20. Requejo R, Hurd TR, Costa NJ, Murphy MP. Cysteine residues exposed on protein surfaces are the dominant intramitochondrial thiol and may protect against oxidative damage. The FEBS journal. 2010; 277(6):1465-1480. [PubMed: 20148960]

21. Messens J, Collet JF. Thiol-disulfide exchange in signaling: Disulfide bonds as a switch. Antioxid Redox Signal. 2013; 18(13):1594-1596. [PubMed: 23330837]

22. Yin Z, Machius M, Nestler EJ, Rudenko G. Activator protein-1: Redox switch controlling structure and DNA-binding. Nucleic Acids Res. 2017; 45(19):11425-11436. [PubMed: 28981703]

23. Ricq EL, Hooker JM, Haggarty SJ. Activity-dependent regulation of histone lysine demethylase kdm1 a by a putative thiol/disulfide switch. J Biol Chem. 2016; 291(47):24756-24767. [PubMed: 27634040]

24. Nishii W, Kukimoto-Niino M, Terada T, Shirouzu M, Muramatsu T, Kojima M, Kihara H, Yokoyama S. A redox switch shapes the lon protease exit pore to facultatively regulate proteolysis. Nat Chem Biol. 2015; 11(1):46-51. [PubMed: 25383757]

25. Ghosh S, Willard B, Comhair SA, Dibello P, Xu W, Shiva S, Aulak KS, Kinter M, Erzurum SC. Disulfide bond as a switch for copper-zinc superoxide dismutase activity in asthma. Antioxid Redox Signal. 2013; 18(4):412-423. [PubMed: 22867017]

26. Wang MY, Ji SR, Bai CJ, El Kebir D, Li HY, Shi JM, Zhu W, Costantino S, Zhou HH, Potempa LA, Zhao J, et al. A redox switch in c-reactive protein modulates activation of endothelial cells. 
FASEB journal : official publication of the Federation of American Societies for Experimental Biology. 2011; 25(9):3186-3196. [PubMed: 21670067]

27. Yi L, Morgan JT, Ragsdale SW. Identification of a thiol/disulfide redox switch in the human bk channel that controls its affinity for heme and co. J Biol Chem. 2010; 285(26):20117-20127. [PubMed: 20427280]

28. Khan MM, Simizu S, Suzuki T, Masuda A, Kawatani M, Muroi M, Dohmae N, Osada H. Protein disulfide isomerase-mediated disulfide bonds regulate the gelatinolytic activity and secretion of matrix metalloproteinase-9. Exp Cell Res. 2012; 318(8):904-914. [PubMed: 22406264]

29. Bowley SR, Fang C, Merrill-Skoloff G, Furie BC, Furie B. Protein disulfide isomerase secretion following vascular injury initiates a regulatory pathway for thrombus formation. Nat Commun. 2017; 8:14151. [PubMed: 28218242]

30. Yoshihara E, Masaki S, Matsuo Y, Chen Z, Tian H, Yodoi J. Thioredoxin/txnip: Redoxisome, as a redox switch for the pathogenesis of diseases. Front Immunol. 2014; 4:514. [PubMed: 24409188]

31. Paulech J, Liddy KA, Engholm-Keller K, White MY, Cordwell SJ. Global analysis of myocardial peptides containing cysteines with irreversible sulfinic and sulfonic acid post-translational modifications. Mol Cell Proteomics. 2015; 14(3):609-620. [PubMed: 25561502]

32. Fetherolf MM, Boyd SD, Taylor AB, Kim HJ, Wohlschlegel JA, Blackburn NJ, Hart PJ, Winge DR, Winkler DD. Copper-zinc superoxide dismutase is activated through a sulfenic acid intermediate at a copper ion entry site. J Biol Chem. 2017; 292(29):12025-12040. [PubMed: 28533431]

33. Sanchez-Gomez FJ, Calvo E, Breton-Romero R, Fierro-Fernandez M, Anilkumar N, Shah AM, Schroder K, Brandes RP, Vazquez J, Lamas S. Nox4-dependent hydrogen peroxide promotes shear stress-induced shp2 sulfenylation and enos activation. Free Radic Biol Med. 2015; 89:419-430. [PubMed: 26427883]

34. Crump KE, Juneau DG, Poole LB, Haas KM, Grayson JM. The reversible formation of cysteine sulfenic acid promotes b-cell activation and proliferation. European journal of immunology. 2012; 42(8):2152-2164. [PubMed: 22674013]

35. Klomsiri C, Rogers LC, Soito L, McCauley AK, King SB, Nelson KJ, Poole LB, Daniel LW. Endosomal h2o2 production leads to localized cysteine sulfenic acid formation on proteins during lysophosphatidic acid-mediated cell signaling. Free Radic Biol Med. 2014; 71:49-60. [PubMed: 24657741]

36. Akerboom TP, Bilzer M, Sies H. The relationship of biliary glutathione disulfide efflux and intracellular glutathione disulfide content in perfused rat liver. J Biol Chem. 1982; 257(8):42484252. [PubMed: 7068633]

37. Alpert AJ, Gilbert HF. Detection of oxidized and reduced glutathione with a recycling postcolumn reaction. Anal Biochem. 1985; 144(2):553-562. [PubMed: 3993916]

38. Giblin FJ, David LL, Wilmarth PA, Leverenz VR, Simpanya MF. Shotgun proteomic analysis of sthiolation sites of guinea pig lens nuclear crystallins following oxidative stress in vivo. Mol Vis. 2013; 19:267-280. [PubMed: 23401655]

39. Hill BG, Bhatnagar A. Protein s-glutathiolation: Redox-sensitive regulation of protein function. J Mol Cell Cardiol. 2012; 52(3):559-567. [PubMed: 21784079]

40. Ji Y, Akerboom TP, Sies H, Thomas JA. S-nitrosylation and s-glutathiolation of protein sulfhydryls by s-nitroso glutathione. Archives of biochemistry and biophysics. 1999; 362(1):67-78. [PubMed: 9917330]

41. Baba SP, Wetzelberger K, Hoetker JD, Bhatnagar A. Posttranslational glutathiolation of aldose reductase (akr1b1): A possible mechanism of protein recovery from s-nitrosylation. Chemicobiological interactions. 2009; 178(1-3):250-258. [PubMed: 19061876]

42. Kaiserova K, Tang XL, Srivastava S, Bhatnagar A. Role of nitric oxide in regulating aldose reductase activation in the ischemic heart. J Biol Chem. 2008; 283(14):9101-9112. [PubMed: 18223294]

43. Conway ME, Coles SJ, Islam MM, Hutson SM. Regulatory control of human cytosolic branchedchain aminotransferase by oxidation and s-glutathionylation and its interactions with redox sensitive neuronal proteins. Biochemistry. 2008; 47(19):5465-5479. [PubMed: 18419134] 
44. Regazzoni L, Panusa A, Yeum KJ, Carini M, Aldini G. Hemoglobin glutathionylation can occur through cysteine sulfenic acid intermediate: Electrospray ionization ltq-orbitrap hybrid mass spectrometry studies. Journal of chromatography B, Analytical technologies in the biomedical and life sciences. 2009; 877(28):3456-3461. [PubMed: 19493711]

45. Greetham D, Grant CM. Antioxidant activity of the yeast mitochondrial one-cys peroxiredoxin is dependent on thioredoxin reductase and glutathione in vivo. Molecular and cellular biology. 2009; 29(11):3229-3240. [PubMed: 19332553]

46. West MB, Hill BG, Xuan YT, Bhatnagar A. Protein glutathiolation by nitric oxide: An intracellular mechanism regulating redox protein modification. FASEB journal : official publication of the Federation of American Societies for Experimental Biology. 2006; 20(10):1715-1717. [PubMed: 16809435]

47. Reynaert NL, van der Vliet A, Guala AS, McGovern T, Hristova M, Pantano C, Heintz NH, Heim J, Ho YS, Matthews DE, Wouters EF, et al. Dynamic redox control of nf-kappab through glutaredoxin-regulated s-glutathionylation of inhibitory kappab kinase beta. Proc Natl Acad Sci U S A. 2006; 103(35):13086-13091. [PubMed: 16916935]

48. Stathopoulou K, Wittig I, Heidler J, Piasecki A, Richter F, Diering S, van der Velden J, Buck F, Donzelli S, Schroder E, Wijnker PJ, et al. S-glutathiolation impairs phosphoregulation and function of cardiac myosin-binding protein $\mathrm{c}$ in human heart failure. FASEB journal : official publication of the Federation of American Societies for Experimental Biology. 2016; 30(5):18491864. [PubMed: 26839380]

49. Lancel S, Zhang J, Evangelista A, Trucillo MP, Tong X, Siwik DA, Cohen RA, Colucci WS. Nitroxyl activates serca in cardiac myocytes via glutathiolation of cysteine 674. Circ Res. 2009; 104(6):720-723. [PubMed: 19265039]

50. Hobbs GA, Mitchell LE, Arrington ME, Gunawardena HP, DeCristo MJ, Loeser RF, Chen X, Cox AD, Campbell SL. Redox regulation of rac1 by thiol oxidation. Free Radic Biol Med. 2015; 79:237-250. [PubMed: 25289457]

51. Thompson MD, Mei Y, Weisbrod RM, Silver M, Shukla PC, Bolotina VM, Cohen RA, Tong X. Glutathione adducts on sarcoplasmic/endoplasmic reticulum ca2+ atpase cys-674 regulate endothelial cell calcium stores and angiogenic function as well as promote ischemic blood flow recovery. J Biol Chem. 2014; 289(29):19907-19916. [PubMed: 24920669]

52. Evangelista AM, Thompson MD, Bolotina VM, Tong X, Cohen RA. Nox4- and nox2-dependent oxidant production is required for vegf-induced serca cysteine- $674 \mathrm{~s}$-glutathiolation and endothelial cell migration. Free Radic Biol Med. 2012; 53(12):2327-2334. [PubMed: 23089226]

53. Zhang X, Taylor A, Liu Y, Shang F. Glutathiolation triggers proteins for degradation by the ubiquitin- proteasome pathway. Current molecular medicine. 2017; 17(4):258-269. [PubMed: 29110605]

54. Dailianis S, Patetsini E, Kaloyianni M. The role of signalling molecules on actin glutathionylation and protein carbonylation induced by cadmium in haemocytes of mussel mytilus galloprovincialis (lmk). The Journal of experimental biology. 2009; 212(Pt 22):3612-3620. [PubMed: 19880721]

55. Townsend DM, Findlay VJ, Fazilev F, Ogle M, Fraser J, Saavedra JE, Ji X, Keefer LK, Tew KD. A glutathione s-transferase pi-activated prodrug causes kinase activation concurrent with sglutathionylation of proteins. Mol Pharmacol. 2006; 69(2):501-508. [PubMed: 16288082]

56. Adachi T, Weisbrod RM, Pimentel DR, Ying J, Sharov VS, Schoneich C, Cohen RA. Sglutathiolation by peroxynitrite activates serca during arterial relaxation by nitric oxide. Nature medicine. 2004; 10(11):1200-1207.

57. Murray CI, Uhrigshardt H, O'Meally RN, Cole RN, Van Eyk JE. Identification and quantification of s-nitrosylation by cysteine reactive tandem mass tag switch assay. Mol Cell Proteomics. 2012; 11(2):M111. 013441.

58. Kohr MJ, Sun J, Aponte A, Wang G, Gucek M, Murphy E, Steenbergen C. Simultaneous measurement of protein oxidation and s-nitrosylation during preconditioning and ischemia/ reperfusion injury with resin-assisted capture. Circ Res. 2011; 108(4):418-426. [PubMed: 21193739]

59. Murray CI, Kane LA, Uhrigshardt H, Wang SB, Van Eyk JE. Site-mapping of in vitro s-nitrosation in cardiac mitochondria: Implications for cardioprotection. Mol Cell Proteomics. 2011; 10(3):M110. 004721. 
60. Greco TM, Hodara R, Parastatidis I, Heijnen HF, Dennehy MK, Liebler DC, Ischiropoulos H. Identification of s-nitrosylation motifs by site-specific mapping of the s-nitrosocysteine proteome in human vascular smooth muscle cells. Proc Natl Acad Sci U S A. 2006; 103(19):7420-7425. [PubMed: 16648260]

61. Chung HS, Wang SB, Venkatraman V, Murray CI, Van Eyk JE. Cysteine oxidative posttranslational modifications: Emerging regulation in the cardiovascular system. Circ Res. 2013; 112(2):382-392. [PubMed: 23329793]

62. Graminski GF, Kubo Y, Armstrong RN. Spectroscopic and kinetic evidence for the thiolate anion of glutathione at the active site of glutathione s-transferase. Biochemistry. 1989; 28(8):3562-3568. [PubMed: 2742854]

63. Manevich Y, Feinstein SI, Fisher AB. Activation of the antioxidant enzyme 1-cys peroxiredoxin requires glutathionylation mediated by heterodimerization with pi gst. Proc Natl Acad Sci U S A. 2004; 101(11):3780-3785. [PubMed: 15004285]

64. Wetzelberger K, Baba SP, Thirunavukkarasu M, Ho YS, Maulik N, Barski OA, Conklin DJ, Bhatnagar A. Postischemic deactivation of cardiac aldose reductase: Role of glutathione stransferase $\mathrm{p}$ and glutaredoxin in regeneration of reduced thiols from sulfenic acids. J Biol Chem. 2010; 285(34):26135-26148. [PubMed: 20538586]

65. Zhang J, Ye ZW, Chen W, Manevich Y, Mehrotra S, Ball LE, Janssen-Heininger YM, Tew KD, Townsend DM. S-glutathionylation of estrogen receptor alpha affects dendritic cell function. J Biol Chem. 2018

66. Mieyal JJ, Gallogly MM, Qanungo S, Sabens EA, Shelton MD. Molecular mechanisms and clinical implications of reversible protein s-glutathionylation. Antioxid Redox Signal. 2008; 10(11):1941-1988. [PubMed: 18774901]

67. Starke DW, Chock PB, Mieyal JJ. Glutathione-thiyl radical scavenging and transferase properties of human glutaredoxin (thioltransferase). Potential role in redox signal transduction. J Biol Chem. 2003; 278(17):14607-14613. [PubMed: 12556467]

68. Cotgreave IA, Gerdes R, Schuppe-Koistinen I, Lind C. S-glutathionylation of glyceraldehyde-3phosphate dehydrogenase: Role of thiol oxidation and catalysis by glutaredoxin. Methods in enzymology. 2002; 348:175-182. [PubMed: 11885270]

69. Sakai J, Li J, Subramanian KK, Mondal S, Bajrami B, Hattori H, Jia Y, Dickinson BC, Zhong J, Ye $\mathrm{K}$, Chang CJ, et al. Reactive oxygen species-induced actin glutathionylation controls actin dynamics in neutrophils. Immunity. 2012; 37(6):1037-1049. [PubMed: 23159440]

70. Chrestensen CA, Starke DW, Mieyal JJ. Acute cadmium exposure inactivates thioltransferase (glutaredoxin), inhibits intracellular reduction of protein-glutathionyl-mixed disulfides, and initiates apoptosis. J Biol Chem. 2000; 275(34):26556-26565. [PubMed: 10854441]

71. Gravina SA, Mieyal JJ. Thioltransferase is a specific glutathionyl mixed disulfide oxidoreductase. Biochemistry. 1993; 32(13):3368-3376. [PubMed: 8461300]

72. Srinivasan U, Mieyal PA, Mieyal JJ. Ph profiles indicative of rate-limiting nucleophilic displacement in thioltransferase catalysis. Biochemistry. 1997; 36(11):3199-3206. [PubMed: 9115997]

73. Yang Y, Jao S, Nanduri S, Starke DW, Mieyal JJ, Qin J. Reactivity of the human thioltransferase (glutaredoxin) c7s, c25s, c78s, c82s mutant and nmr solution structure of its glutathionyl mixed disulfide intermediate reflect catalytic specificity. Biochemistry. 1998; 37(49):17145-17156. [PubMed: 9860827]

74. Barrett WC, DeGnore JP, Konig S, Fales HM, Keng YF, Zhang ZY, Yim MB, Chock PB. Regulation of ptp1b via glutathionylation of the active site cysteine 215. Biochemistry. 1999; 38(20):6699-6705. [PubMed: 10350489]

75. Wang J, Tekle E, Oubrahim H, Mieyal JJ, Stadtman ER, Chock PB. Stable and controllable rna interference: Investigating the physiological function of glutathionylated actin. Proc Natl Acad Sci U S A. 2003; 100(9):5103-5106. [PubMed: 12697895]

76. Adachi T, Pimentel DR, Heibeck T, Hou X, Lee YJ, Jiang B, Ido Y, Cohen RA. S-glutathiolation of ras mediates redox-sensitive signaling by angiotensin ii in vascular smooth muscle cells. J Biol Chem. 2004; 279(28):29857-29862. [PubMed: 15123696] 
77. Pan S, Berk BC. Glutathiolation regulates tumor necrosis factor-alpha-induced caspase-3 cleavage and apoptosis: Key role for glutaredoxin in the death pathway. Circ Res. 2007; 100(2):213-219. [PubMed: 17185628]

78. Bachschmid MM, Xu S, Maitland-Toolan KA, Ho YS, Cohen RA, Matsui R. Attenuated cardiovascular hypertrophy and oxidant generation in response to angiotensin ii infusion in glutaredoxin-1 knockout mice. Free Radic Biol Med. 2010; 49(7):1221-1229. [PubMed: 20638471]

79. Watanabe Y, Cohen RA, Matsui R. Redox regulation of ischemic angiogenesis- another aspect of reactive oxygen species. Circulation journal : official journal of the Japanese Circulation Society. 2016; 80(6):1278-1284. [PubMed: 27151566]

80. Song Y, Shan Z, Luo C, Kang C, Yang Y, He P, Li S, Chen L, Jiang X, Liu L. Glutathione stransferase $\mathrm{t} 1$ (gstt1) null polymorphism, smoking, and their interaction in coronary heart disease: A comprehensive meta-analysis. Heart Lung Circ. 2017; 26(4):362-370. [PubMed: 27686690]

81. Ndrepepa G, Kastrati A. Gamma-glutamyl transferase and cardiovascular disease. Ann Transl Med. 2016; 4(24):481. [PubMed: 28149843]

82. Sheeran FL, Pepe S. Mitochondrial bioenergetics and dysfunction in failing heart. Adv Exp Med Biol. 2017; 982:65-80. [PubMed: 28551782]

83. Robaczewska J, Kedziora-Kornatowska K, Kozakiewicz M, Zary-Sikorska E, Pawluk H, Pawliszak W, Kedziora J. Role of glutathione metabolism and glutathione-related antioxidant defense systems in hypertension. J Physiol Pharmacol. 2016; 67(3):331-337. [PubMed: 27511994] 


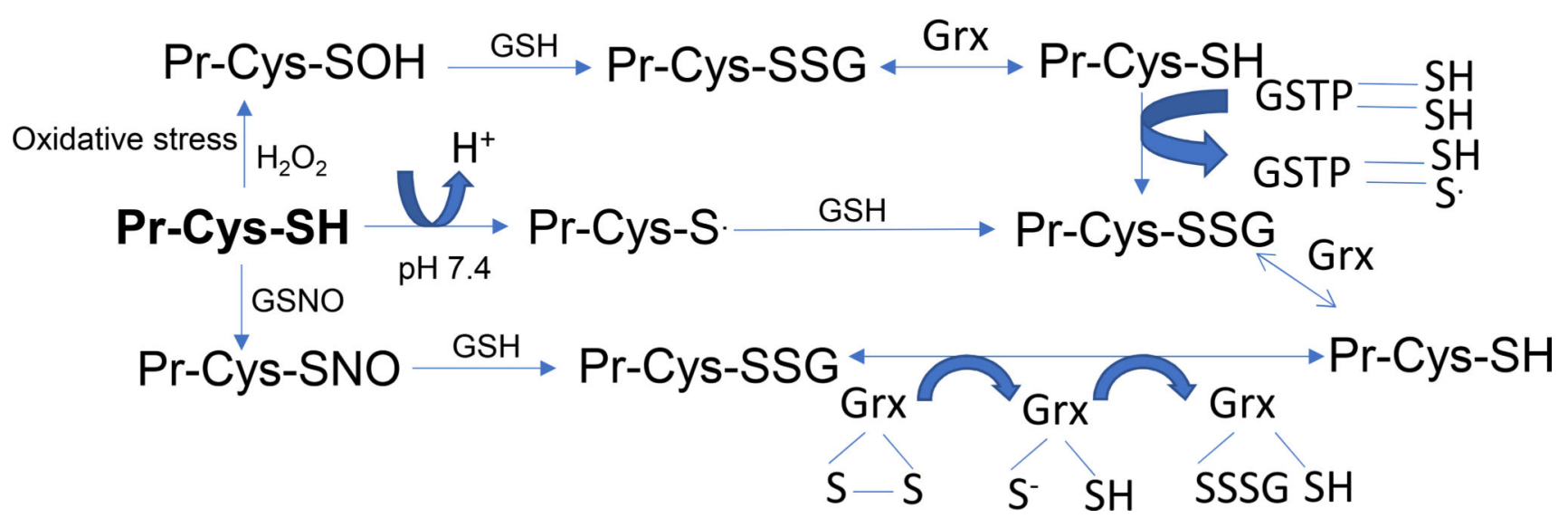

Figure 1. Pathways of protein modification regulated by glutathione The figure depicts the modification of protein cysteine thiols ( $\mathrm{Pr}-\mathrm{Cys}-\mathrm{SH}$ ) during oxidative and nitrosative stress. Reactive oxygen and nitrogen species react with the specific Pr-Cys$\mathrm{SH}$ to form cysteine sulfenic acid $(\mathrm{SOH})$ and $S$-nitrocysteine (Pr-Cys-NO) intermediates respectively. These intermediates bind with glutathione (GSH) to generate glutathiolated protiens (Pr-Cys-SSG). Glutathiolation of proteins can be accelerated by GSTP (glutathione S-transferase P) and Grx (glutaredoxin) mediated reactions. Deglutathiolation of Pr-CysSSG is predominantly catalyzed by Grx. 